\title{
Heavy and light minerals as a tool for reconstructing depositional environments: an example from the Jałówka site (northern Podlasie region, NE Poland)
}

\author{
Barbara Woronko, ${ }^{1, *}$, Joanna Rychel ${ }^{2}$, Mirosław T. Karasiewicz ${ }^{3}$, Andrzej Ber ${ }^{2}$, \\ Tomasz Krzywicki², Leszek Marks² \& Katarzyna Pochocka-Szwarc ${ }^{2}$ \\ ${ }^{1}$ Faculty of Geography and Regional Studies, University of Warsaw, Krakowskie Przedmieście 30, \\ 00-927 Warsaw, Poland; e-mail: bworonko@uw.edu.pl \\ ${ }^{2}$ Polish Geological Institute-National Research Institute, Rakowiecka 4, 00-975 Warsaw, Poland; \\ e-mail: joanna.rychel@pgi.gov.pl; andrzej.ber@pgi.gov.pl; tomasz.krzywicki@pgi.gov.pl; leszek.marks@pgi.gov.pl; \\ katarzyna.pochocka-szwarc@pgi.gov.pl \\ ${ }^{3}$ Faculty of Earth Sciences, Nicolaus Copernicus University, Lwowska 1, 87-100 Torun, Poland; \\ e-mail: mtkar@umk.pl \\ *corresponding author
}

\begin{abstract}
Part of northern Podlasie (NE Poland), shaped during the Wartanian stadial of the Odranian glaciation (Saalian), was situated in the periglacial zone during the Vistulian (Weichselian) glaciation. Both landforms and sediments were affected by the periglacial conditions. This is recorded at the Jałówka site, at the floor of a dry valley, where mineral deposits of $4.13 \mathrm{~m}$ thick, overlying organic deposits from the Eemian interglacial, were examined. These mineral deposits form four units, from bottom to top: a fluvial unit (I), a loess-like unit (II), a solifluction unit (III), and an aeolian unit with ice wedges (IV) on top of unit III. The heavy and light minerals were analysed, as well as the geochemistry, in order to find out about the parent material and to reconstruct the climatic conditions during deposition. The mineral analysis indicates that the Saalian till was predominantly derived from shallow-marine deposits; erosion accompanied by sorting of the heavy minerals took place on the basis of their mass and grain size. The original material of the till seems therefore to be sedimentary rocks from the eastern Central Baltic Basin. This material became strongly weathered under the periglacial conditions, resulting in the destruction of the quartz grains, as well as in leaching, leading to complete decalcification of the deposits. Aeolian activity resulted in infilling of ice wedges and the creation of thin layers. The intensity and the duration of these processes was limited, so that the effects of the aeolian abrasion are insignificant. Neither resulted the aeolian activity in significant reshaping of the landscape.
\end{abstract}

Key words: heavy minerals, quartz grains, periglacial processes, source deposits, Vistulian glaciation, NE Poland

\section{Introduction}

The northern part of the Podlasie region (NE Poland) has a varied relief (Fig. 1), resulting from processes associated with the presence and recession of the ice sheet of the Late
Glacial of the Wartanian stadial of the Odranian glaciation (Saalian; Ehlers \& Gibbard, 2008) and with processes active during the Eemian interglacial and the Vistulian (Weichselian) glaciation, when the area was situated, most likely repeatedly (undoubtedly during the Last 


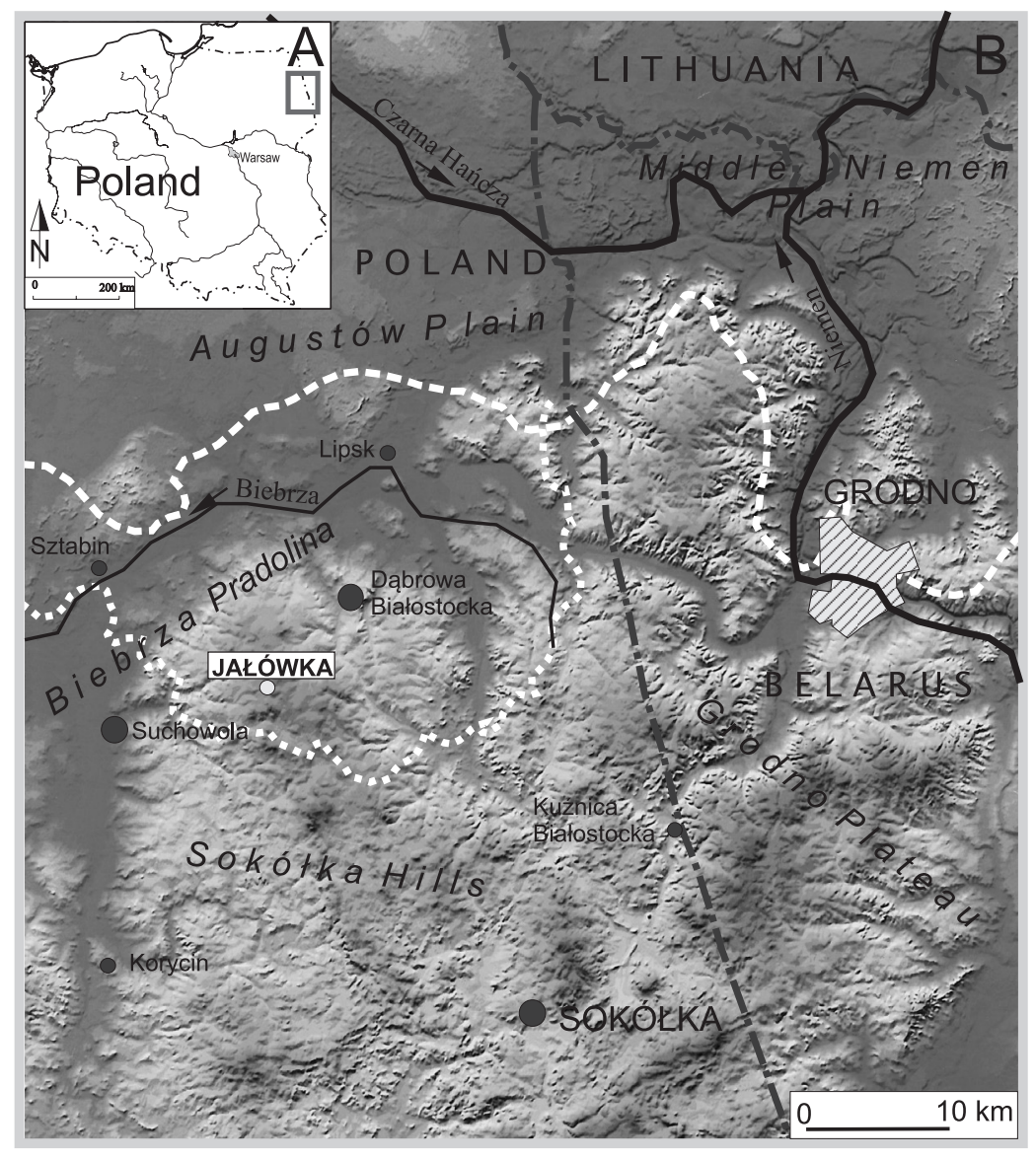

Fig. 1. Location map.

A: Location of Poland and the study site, B. Detailed map showing the Jałówka site and the maximum ice extent during the Last Glacial Maximum (dashed line) and the hypothetical ice lobe of the Świecie Stadial (dotted line).
Glacial Maximum, LGM), in the periglacial zone (Korotaj \& Mycielska-Dowgiałło, 1982; Dzierżek \& Stańczuk, 2006). Up to now, investigation of this region focused mainly on issues such as (1) identification and description of the lithological variability of the sediments (Micun, 2008, 2009), and (2) climate change during the Eemian interglacial (Kupryjanowicz, 2008). Some of the numerous sections of Eemian deposits of this area bear a record of the first post-Eemian cooling and of the beginning of the first Vistulian interstadial (Kuprjanowicz, 1991, 2008; Brud \& Kupryjanowicz, 2002). The analyses were focused particularly, however, on (3) detailing the Last Glacial Maximum of the Vistulian glaciation (e.g. Banaszuk, 1998, 2001; Micun, 2004, 2006 2008; Banaszuk \& Banaszuk, 2010), including the middle stadial of this glaciation, i.e. the Swiecie stadial (MIS 4) (e.g. Krzywicki, 2002, 2012; Mojski, 2005).

The Vistulian palaeogeography of this region nevertheless is still poorly understood, particularly regarding the hypothesis put forward by Dylik (1953) of the polygenetic origin of the mid-Polish relief. He assumed that the landform shaped by successive ice sheets was affected by a periglacial cycle that distinctly modified the relief and the sediments. In this context, reconstruction of changes in the environmental conditions of the northern part of the Podlasie region during the Vistulian is important for several reasons: in the first place because of the maximum extent of the Vistulian ice sheet and in the second place because of the intensity of the changes in relief and sediments under periglacial conditions. The above-mentioned issues can be discussed well on the basis of the Jałówka site $\left(53^{\circ} 35^{\prime} 44,4^{\prime \prime} \mathrm{N}\right.$, $23^{\circ} 14^{\prime} 52,1^{\prime \prime} \mathrm{E}$; Fig. 1), which is a representative example. It is located within the Sokólskie Hills, approx. $20 \mathrm{~km}$ south of the Last Glacial Maximum (LGM) of the Vistulian Glaciation, which has been reconstructed on the basis of detailed cartographic studies (Wrotek, 2009; Marks \& Karabanov, 2011) and which is dated as 19-20 ka (Marks, 2012). The site is situated on the periphery of moraines that indicate the hypothetical limit of an ice lobe associated 
with the Last Glacial Maximum of the middle part of the Vistulian glaciation (the Świecie stadial), distinguished by some workers who mapped sheets of the 'Detailed geological map of Poland' (cf. Marks \& Karabanov, 2011) (Fig. 1).

The development or disappearance of successive Pleistocene ice sheets, as well as the intensity of processes active in their foreland, is recorded in a wide variety of organic and mineral sediments. Reconstruction of these changes provides a basis for understanding the underlying mechanisms and may help to predict possible climate changes likely to occur in the future. This aim may be achieved with the help of numerous detailed sedimentological (including heavy-mineral), geochemical, palaeobotanical and other analyses.

In geological, geomorphological and sedimentological research, the analysis of heavy and light minerals has been applied to reconstructions of the type of environment (Łydka \& Turnau-Morawska, 1967; Mycielska-Dowgiałło, 1992, 1993; Korotaj \& Mycielska-Dowgiałło, 1982; Kamińska et al., 1986; Florek \& Mycielska-Dowgiałło, 1991; Vieira et al., 2003; Woronko, 2001, 2012a; Derkachev \& Nikolaeva, 2013), intensity and type of weathering (Van Loon, 1972/1973, 2009; Bateman \& Catt, 2007; Durn et al., 2007; Woronko \& Hoch, 2011), dynamics of processes (Kamińska et al., 1986; Florek et al., 1987; Rizzetto et al., 1998; Barczuk \& Mycielska-Dowgiałło, 2001; Komar, 2007; Weckwerth \& Chabowski, 2013), sources of deposits (Rappol \& Stoltenberg, 1985; Mycielska-Dowgiałło \& Cichosz-Kostecka, 1987; Haldorsen et al., 1989; Passchier, 2007; Morton, 2013; Ludwikowska-Kędzia, 2013; Wachecka-Kotkowska \& Ludwikowska-Kędzia, 2013), as well as of all kinds of post-sedimentation processes affecting the sediment (e.g. Bateman, 1989; Bateman \& Catt, 2007; Weibel \& Friis, 2007; Marcinkowski \& Mycielska-Dowgiałło, 2013). The thick succession of mineral sediments exposed at the Jałówka site was therefore subjected to examinations of heavy and light minerals and geochemical analyses.

The main issues on which the present contribution focuses, based on heavy and quartz grains and geochemical analysis of deposits, are (1) the conditions during sediment accumulation, and the post-sedimentary processes affecting the sediments at the Jałówka site (Fig. $1)$, (2) transport and depositional processes, and (3) the likely source areas of the Jałówka sediments.

\section{Geographical and geological setting}

The Jałówka site is situated at the foot of the wall of a vast, flat-bottomed, NW-SE oriented, dry valley. The wall faces the NW and has an inclination of approx. $5^{\circ}$. The longitudinal section of the valley is irregular. The valley floor shows small, wet depressions, most likely developed due to compaction of organic deposits formed during the Eemian interglacial (Kupryjanowicz, 2008; Micun, 2009). The dry valley cuts through end-moraines constituting hills with a relative altitude of some $20 \mathrm{~m}$.

In 2011, a pilot drilling performed at the Jałówka site revealed the presence in a shallow depression of biogenic deposits from a depth of $4.13 \mathrm{~m}$ downwards; they are overlain by mineral sediments. In order to investigate the structure of the mineral deposits, an outcrop was dug.

\subsection{The organic sediments}

Results of a palynological analysis indicate that deposition of organic sediments within the basin in the dry valley began in the Late Glacial of the Wartanian stadial of the Odranian glaciation (Fig. 2) and was followed by uninterrupted sedimentation until the climatic optimum of the Eemian interglacial. The lack of sediments between the optimum and the end of the interglacial suggests erosion, most likely at the transition of the Eemian (MIS 5e) to the Early Glacial (stages 5d-e) (Rychel et al., in press). The erosion/incision phase is commonly recorded in the floors of West European river valleys (Kasse et al., 2003; Briant et al., 2004) and is associated with an increase in water supply, resulting from decreasing evapotranspiration and increasing snowmelt (Kasse et al., 2003). 


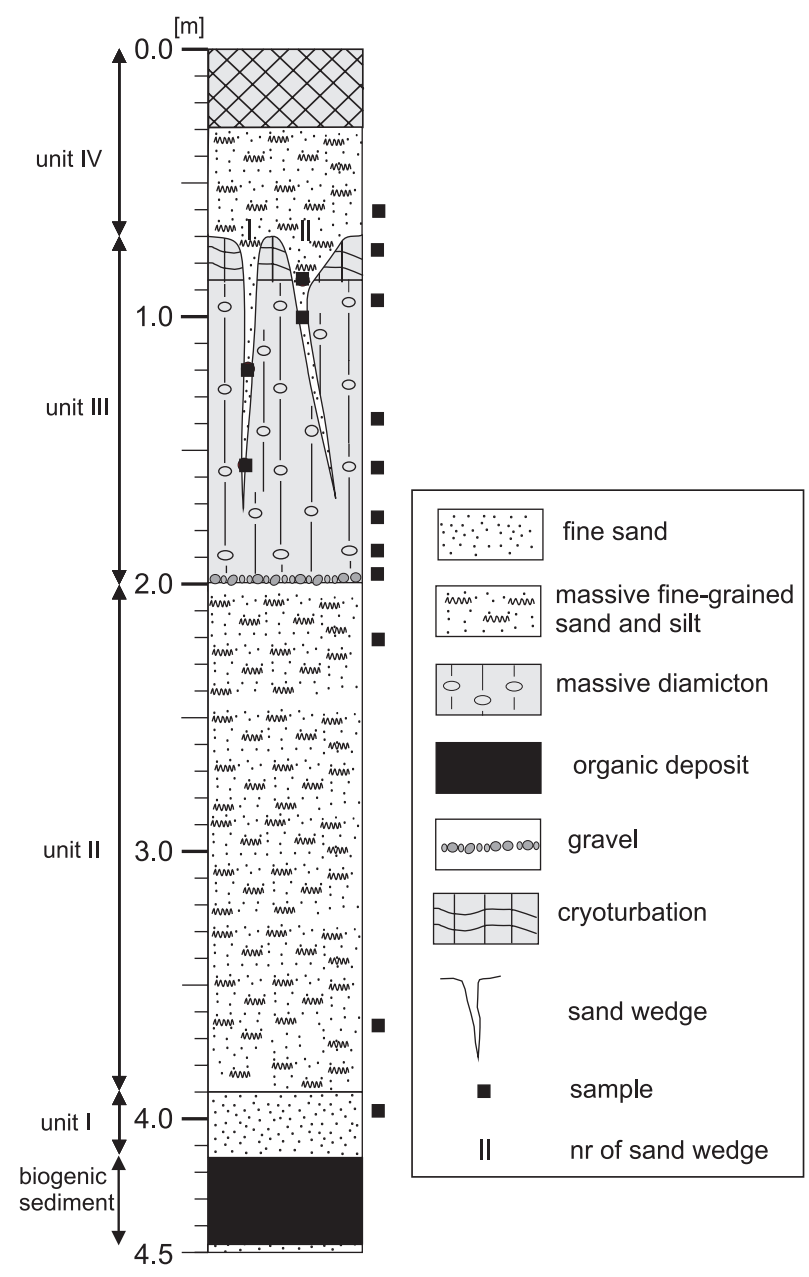

Fig. 2. Vertical profile of the Vistulian mineral deposits and the Eemian organic deposits at the Jałówka site.

\subsection{The mineral deposits}

The organic sediments are overlain by 4.13-m-thick mineral deposits in which four units (I-IV) are distinguished (Fig. 2). Unit I comprises wet silty sands (depth: 4.13-3.9 m; Fig. 2) with climbing ripple (Src). The structures of the sediments indicate low-energy currents in the bottom of the more commonly dry valley.

Unit II consists of non-stratified, fine-grained sand and sandy loam, 1.9 m thick at a depth of 3.9-2.0 m (Fig. 2). The sediments contain an uncommonly high proportion of grains of the $0.1-0.05 \mathrm{~mm}(53.12 \%)$ and $0.05-0.01 \mathrm{~mm} \mathrm{(10 \% )}$ fractions, which suggests loess-like sediments.

Unit III consists of a massive silty/clayey diamicton of $1.3 \mathrm{~m}$ thick $(2.0-0.7 \mathrm{~m})$. It contains coarse gravel particles, up to $5 \mathrm{~cm}$ long, in its basal part. This unit probably represents sediments resulting from slope processes (solifluction) (Fig. 2), developed under periglacial conditions on a loamy slope dipping some $5^{\circ}$, which was approx. $150 \mathrm{~m}$ long. The precise time of the intensive slope processes that modelled the slopes of the northern part of the Podlasie region is still unknown. The considerable thickness of the loamy sediments suggests, however, long-lived slope processes and overlapping of successive solifluction lobes. The top part of unit III (depth: $1.20-0.70 \mathrm{~m}$ ) shows a network of reticulate cryostructures resulting from the presence of interconnected subhorizontal ice lenses and subvertical ice veins (cf. French \& Shur, 2010; Stephani et al., 2010; Van Vliet-Lanoë, 2010). This reticulate cryogenic texture is formed when the freezing front progressively moves downwards from the surface (French \& Shur, 2010).

Additionally, the top of unit III houses two generations of ice-wedge casts filled with sand; these infillings constitute unit IV (Fig. 2). The structures of the older generation (no I), approx. $1 \mathrm{~m}$ deep, wide in their upper part and narrow in the lower one, are clearly modified by slope processes (consistent with the slope inclination). The structures of the younger generation (no II) have a similar length, but they are straight and narrow over their entire extent and filled with sandy material. The southern part of the Podlasie region bears a record of two generations of wedges with initial sand infilling. One generation is correlated, on the basis of TL dating as $49 \pm 7 \mathrm{ka}$ to $43 \pm 7 \mathrm{ka}$, with the global climatic cooling of Heinrich event H5. The younger one $(23 \pm 4 \mathrm{ka})$ fits in the Last Glacial Maximum (Heinrich event H2) (Dzierżek \& Stańczuk, 2004).

The Unit III sediments are overlain by massive silty sands (Unit IV; 0.7-0.0 m deep), which have an aeolian origin (Rychel et al., 2011).

The presence of Eemian sediments in the basal part of the section, in combination with the ice-wedge casts that can be correlated with the LGM in the top part, suggests that the sediments from the Jałówka site are likely to record changes in the environmental conditions for the last $100 \mathrm{ka}$, i.e. during the Vistulian glaciation. Regrettably, the analysed material was 
unsuitable for absolute dating by means of physical methods.

\section{Methods}

In order to reconstruct the palaeoenvironment and sedimentary conditions of the mineral sediments at the Jałówka site, they were subjected to comprehensive sedimentological study. Samples were selected so as to represent the widest possible variation in lithology and stratigraphy.

\subsection{Heavy-mineral analysis}

Analysis of the heavy minerals was carried out for the $0.1-0.2 \mathrm{~mm}$ fraction. The heavy minerals were identified under polarised light. Over 400 grains were counted in each sample. Transparent and opaque heavy minerals together were taken as $100 \%$.

\subsubsection{Weathering}

The intensity of the weathering affecting the surface of the heavy minerals was established, as well as the resulting consequences for shape, fraction and sorting. The analysis included calculations of the non-dimensional weathering index $\left(\mathrm{W}_{1}\right)$. This was done taking transparent and opaque heavy minerals together as $100 \%$, which differs from the original weathering index (W) (Racinowski \& Rzechowski, 1969), where only transparent heavy minerals were taken as $100 \%$. $\mathrm{W}_{1}$ is defined as:

$$
\mathrm{W}_{1}=(\mathrm{St} / \mathrm{T}) \times \mathrm{N}
$$

where $\mathrm{T}$ is the content (in \%) of the heavy minerals that are most strongly resistant to both mechanical abrasion and chemical weathering (zircon, rutile, tourmaline, staurolite, kyanite), St is the content (in \%) of the strongly resistant heavy minerals (apatite, epidote, garnet, sillimanite), and $\mathrm{N}$ is the content (in \%) of the non-resistant heavy minerals (amphibole, pyroxene, biotite, chlorite). The lower the value of the weathering index, the more advanced the weathering.

\subsection{Rounding and frosting of quartz grains}

The rounding and frosting of quartz grains were examined on the basis of the method described by Cailleux (1942), as modified by Goździk (1980) and Mycielska-Dowgiałło \& Woronko (1998), with the application of a 9-degree classification of the grain shape by Krumbein (1941). Over 150 grains were counted in each sample.

Seven rounding and frosting classes were distinguished in the sand fraction: (1) fresh, angular (NU, rounding degree: 0.1-0.2, following Krumbein), (2) aeolian: rounded and mat (RM, rounding degree: 0.7-0.9), (3) high-energy, aquatic environment: rounded and shiny (EL, rounding degree: 0.7-0.9), (4) moderately aeolian: mat (EM/RM, rounding degree: 0.3$0.6)$, (5) moderately high-energy, aquatic environment (EM/EL, rounding degree: 0.3-0.6), (6) broken (C) within classes 2-5 (this group includes grains with at least a $30 \%$ loss of the original grain surface), and (7) other grains, weathered in situ, not affected by transport.

\subsection{Geochemistry}

A simplified geochemical analysis $(\mathrm{Na}, \mathrm{Mg}$, $\mathrm{Ca}, \mathrm{K}, \mathrm{Fe}$ and $\mathrm{Mn}$ ) was also performed. The total content of the selected chemical elements was determined after the samples had been dissolved in a mixture of $\mathrm{HNO}_{3}$ and $\mathrm{H}_{2} \mathrm{O}_{2}$ with the use of a Milestone Ethos Plus microwave apparatus. From the thus obtained solutions, the amounts of $\mathrm{Na}$ and $\mathrm{K}$ were identified by means of emission spectrophotometry (ES); the amounts of $\mathrm{Ca}, \mathrm{Mg}$, Fe and Mn were determined with atomic absorption spectrophotometry (AAS).

\section{Results}

\subsection{Heavy-mineral composition}

The composition of the heavy minerals is very similar for all units (I-IV), as they are all characterised by a limited number of mineral species and because they are all dominated by 


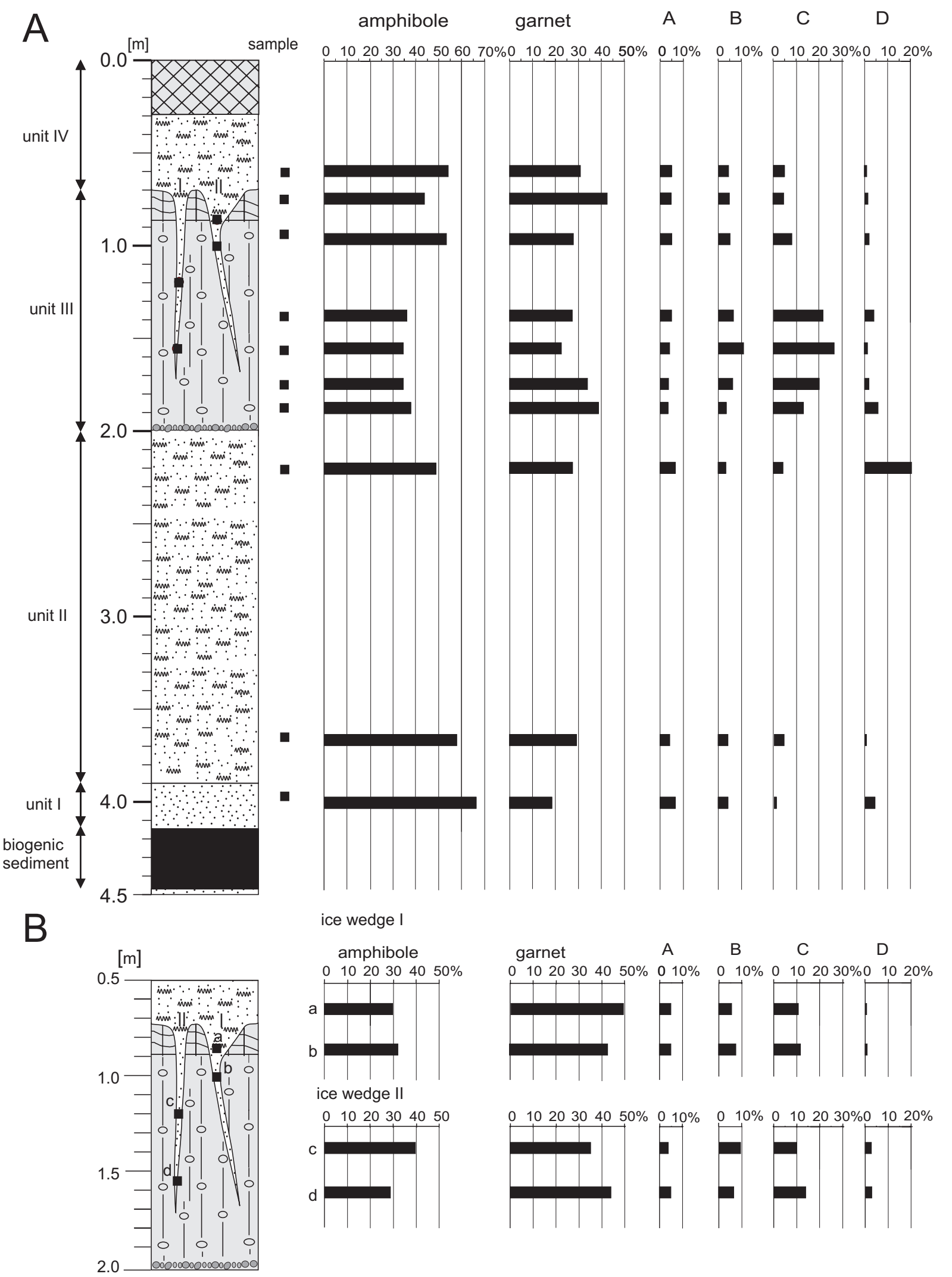

Fig. 3. Heavy-mineral composition of the mineral deposits.

$\mathrm{A}=$ sum of biotite, chlorite, epidote, pyroxene, apatite and sillimanite; $\mathrm{B}=$ sum of the heavy minerals that are most resistant to both abrasion and weathering; $C=$ sum of primary iron oxides; $D=$ sum of secondary iron oxides. A: units I-III, B: unit IV (ice wedges filled with aeolian deposits). 
two species: amphibole and garnet (Fig. 3A, $B)$, though with varying $A / G$ ratios. This ratio amounts to 3.71 in the sediments of unit I and to 2.96-2.06 in unit II. In the massive, silty/ clayey diamicton of unit III, the ratio ranges from 1.00 to 1.94, while it decreases in the infilling of the ice wedges and the silty/sandy sediments of unit IV to below a value of 1 . Moreover, strongly resistant minerals (rutile, tourmaline, staurolite and kyanite) are present in truly low numbers, not exceeding $2.0 \%$, except for zircon, which increases to over $4 \%$ in the sediments of unit III and in the infilling of the ice-wedge casts. The platy minerals with low resistance to weathering (biotite and chlorite) are present in low concentrations, not over $2 \%$; they are even completely absent in unit IV in the infilling of the wedges. Glauconite and muscovite are entirely absent (Fig. 3B).

The sediments of units I-III contain angular heavy minerals with ragged edges, traces of corrosion and colour spots, varying from, for instance, pale green to slightly grey in amphiboles. This is due to surface damage caused by different intensities of etching. Only the aeolian sediments of unit IV contain grains with slightly rounded edges. It should also be noted that the grains of different mineral species differ in size (Fig. 3B): amphibole grains $(\sim 0.2$ $\mathrm{mm})$ are twice as large as garnet grains $(\sim 0.1$ $\mathrm{mm}$ ) and zircon grains (representing the finest fraction in samples), are, in turn, much smaller than garnet grains.

The opaque heavy minerals are dominated by primary ferric oxides (ilmenite and magnetite). In the massive, silty/clayey diamicton (unit III), their proportion is very high and attains $13.4 \%$ in the basal part, $20-26 \%$ in the middle part and $5.1 \%$ in the top part. The sediments of units II and IV contain approx. 10\% (Fig. 3A, B) of such minerals, but unit I contains only $1.1 \%$ of primary ferric oxides (Fig. 3A). Secondary ferric oxides (limonite and goethite) are present in minor amounts. Their amount does, as a rule, not exceed $5 \%$, and in the aeolian sediments of unit IV and in the infillings of the wedges their proportion decreases even to below 2\% (Fig. 3B); only in the top of unit II, it attains as much as $19.5 \%$. None of the samples comprises pyrite (Fig. 3A, B), which min- eral is considered as an indicator of short-lived transport and which is easily oxidised to ferric sulphides, dissolved in water and leached (Barczuk \& Najbert, 2007).

\subsection{Rounding and frosting}

The analysis following the method described above indicates that the mineral sediments of units I, II and III are dominated in the 0.8-1.0 $\mathrm{mm}$ fraction by three types of quartz grains. The EL and EM/EL classes, representing an aquatic environment (including fluvial and high-energy beach environments) are found in proportions attaining $18 \%-48.2 \%$ in unit I, $28.2-55.0 \%$ in unit II and $28.9-60.5 \%$ in unit III (Fig. 4A). The large amounts of exceptionally well-rounded grains with a shiny surface must be noted (EL; Fig. 5A), but examination under a scanning electron microscope (SEM) indicates that the surface of such grains was affected by intensive chemical etching, forming microstructures resulting in a dulled surface, solution pits and solution crevasses (Fig. 5B). The second important group comprises grains of the 'other' type, the surface of which was shaped by intensive chemical weathering (mainly amorphous precipitation) and mechanical (frost) weathering, occurring in situ. Their proportion in the sediments of units I-III ranges from $18.0 \%$ to even $73 \%$ in the bottom part of unit I (Fig. 4A).

The high or very high proportion of broken grains (C) is also worth attention. They originate from breakage of grains of the EL, EM/ EL and 'other' types and occur all over the entire succession in amounts exceeding 10\% (except for the basal part of the sediments of units I and IV). The two top units, III and IV, have a high content of grains of type $\mathrm{C}$, ranging from $15 \%$ up to nearly $40 \%$ (Fig. 4A). Some conchoidal fractures resulting from breakage are completely fresh, which indicates at an origin during the last damaging cycle; other grains show a low degree of precipitation of amorphous silica and clay minerals, e.g. in the sediments of unit I. Grains affected by aeolian processes (EM/RM and RM) were not found in the sediments of units I-III, in contrast to 


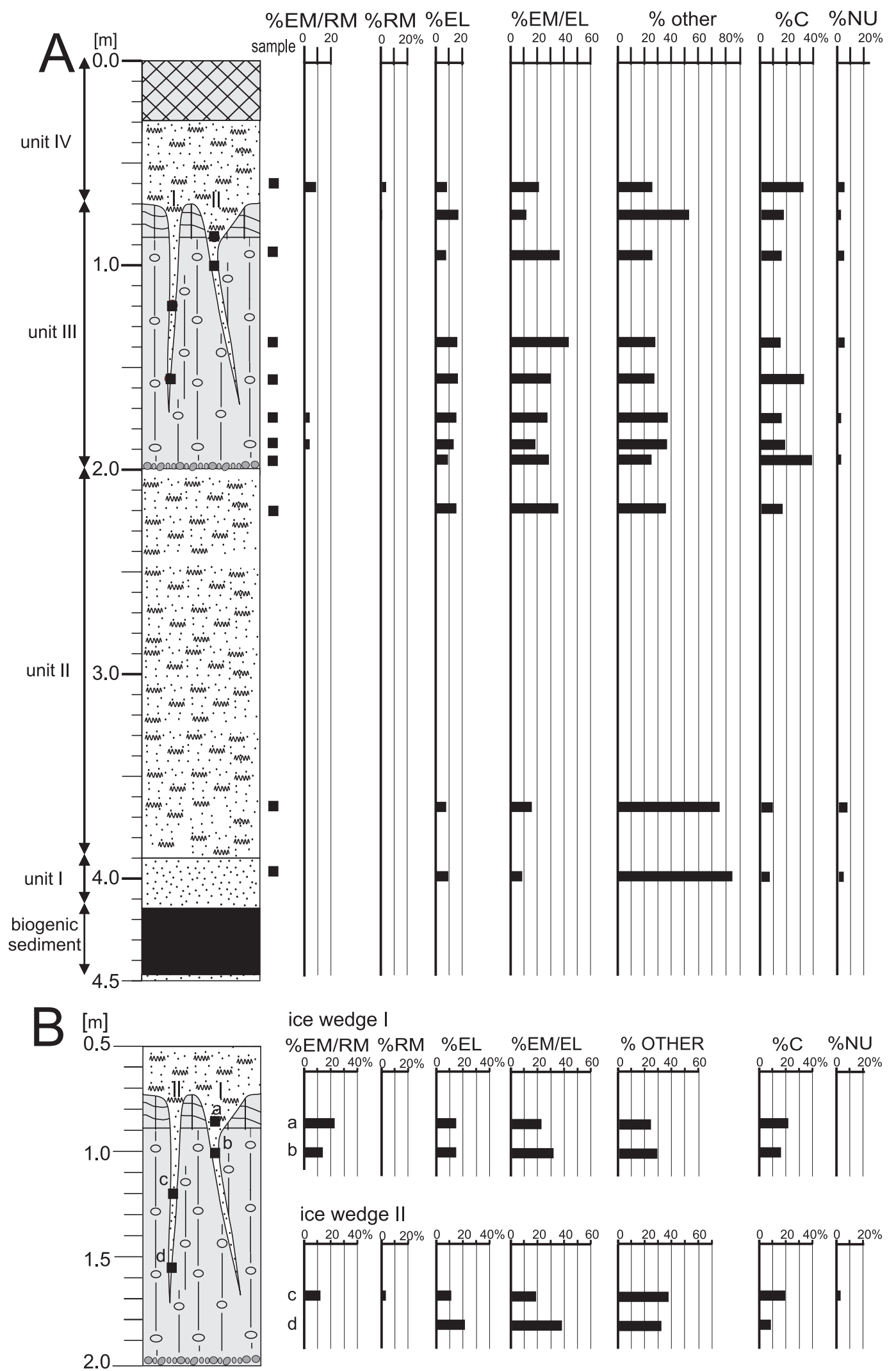

Fig. 4. Rounding and frosting of the quartz grains.

$\mathrm{NU}=$ fresh, angular; $\mathrm{RM}=$ rounded and mat; $\mathrm{EL}=$ rounded and shiny; $\mathrm{EM} / \mathrm{RM}=$ moderately rounded and mat; $\mathrm{EM} / \mathrm{EL}=$ moderately rounded and shiny; $\mathrm{C}=$ broken; other grain $=$ weathered in situ.

A: units I-III. B: unit IV (ice wedges filled with aeolian deposits). 

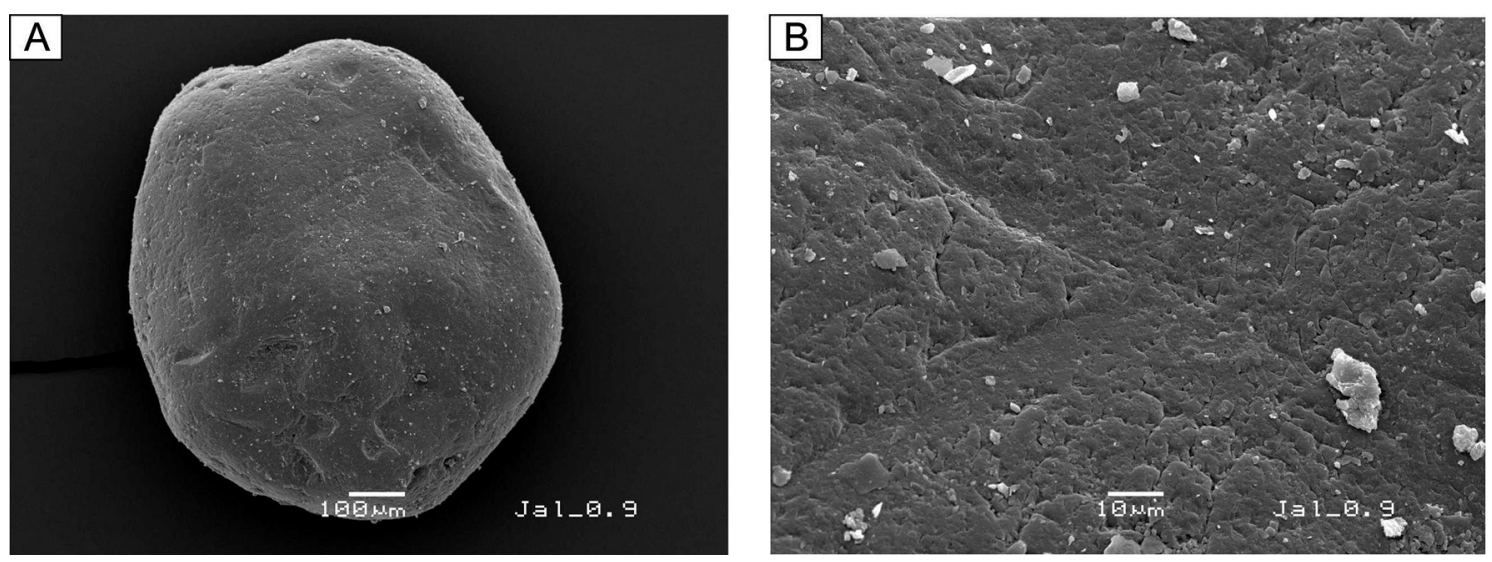

Fig. 5. Quartz-grain characteristics.

A: Very well rounded quartz grain $(0.8-1.0 \mathrm{~mm})$ representing a high-energy subaqueous environment (type EM/ EL).

B: Fragment of a quartz grain with dull surface with small solution pits and solution crevasses, showing a low concentration of V-shaped percussion cracks (unit III, depth 0.9-0.1.0 m).

the upper parts of the infillings of the icewedge casts and the sandy/silty sediments of unit IV, where the proportion of such grains attains $21 \%$ (Fig. 4B). It should be emphasised, however, that exclusively the edges and corners of these grains are affected by the aeolian activity.

\subsection{Weathering}

The weathering index, $\mathrm{W}_{1}$, shows comparable values, ranging from 296.3 to 226.8, in the sediments of units I and II (Fig. 6A). In the sediments of unit III, however, the values vary much more: being 427.8 at the base, they decrease to 185.6 at a depth of 1.7-1.75 $\mathrm{m}$ and further to 78.2 at a depth of $1.55-1.60 \mathrm{~m}$, to increase again to 297.4 and 457.1 at the top of unit (depth of $0.75 \mathrm{~m}$ ). The low value of $\mathrm{W}_{1}$ in the middle part of unit III records an increase in the amount of minerals that are strongly resistant to weathering, and the diminishing of the least resistant minerals. In the sandy sediments filling the wedges, $W_{1}$ varies between 253.6 and 159.4 in the basal part to attain 221.7 at a depth of $1.0 \mathrm{~m}$ and 322.4 in the top part. The sandy sediments of unit IV, which constitute the uppermost part of the succession under study, have a $W_{1}$ value of 384.9, suggesting removal of heavy minerals with a lower resistance to chemical weathering (Fig. 6B).

\subsection{Geochemistry}

\subsubsection{The Eemian organic sediments}

The Eemian biogenic sediments, underlying the mineral units, are abundant in sodium (up to $0.55 \mathrm{mg} \bullet \mathrm{g}^{-1}$ ), potassium (up to $13.03 \mathrm{mg} \bullet \mathrm{g}^{-1}$ ), calcium (up to $92.7 \mathrm{mg}^{\bullet} \mathrm{g}^{-1}$ ), magnesium (up to $12.2 \mathrm{mgvg}^{-1}$ ), iron (up to $24.7 \mathrm{mg} \bullet \mathrm{g}^{-1}$ ), manganese (up to $0.27 \mathrm{mg} \bullet \mathrm{g}^{-1}$ ) and carbonates (even up to $45 \%$ in gyttja) (Fig. 7). The calculated values of the $\mathrm{K} / \mathrm{Na}$ and $\mathrm{Fe} / \mathrm{Mn}$ ratios clearly reflect changing environmental conditions in the basin (Rychel et al., in press) and suggest phases of increased denudation, due to both chemical and mechanical processes, in the catchment area, as well as changes in the redox conditions that resulted from the expansion of the vegetation cover in the water basin, which thus gradually turned into a peat bog.

\subsubsection{The Vistulian mineral deposits}

The mineral sediments (excluding unit I) are decalcified and poor, or even extremely poor, in the above-mentioned chemical elements, what must probably be ascribed to strong and long-lived weathering processes affecting the deposits.

The carbonate sediments of unit I (up to $11 \%$ of $\left.\mathrm{CaCO}_{3}\right)$ show an alkaline reaction $(\mathrm{pH}$ of 8.6-9.0 determined in $\mathrm{H}_{2} \mathrm{O}$ and 7.6-7.8 in $\mathrm{KCl}$ ). Only at the base of the mineral succession (4.12 $\mathrm{m}$ depth), carbonates reach have 


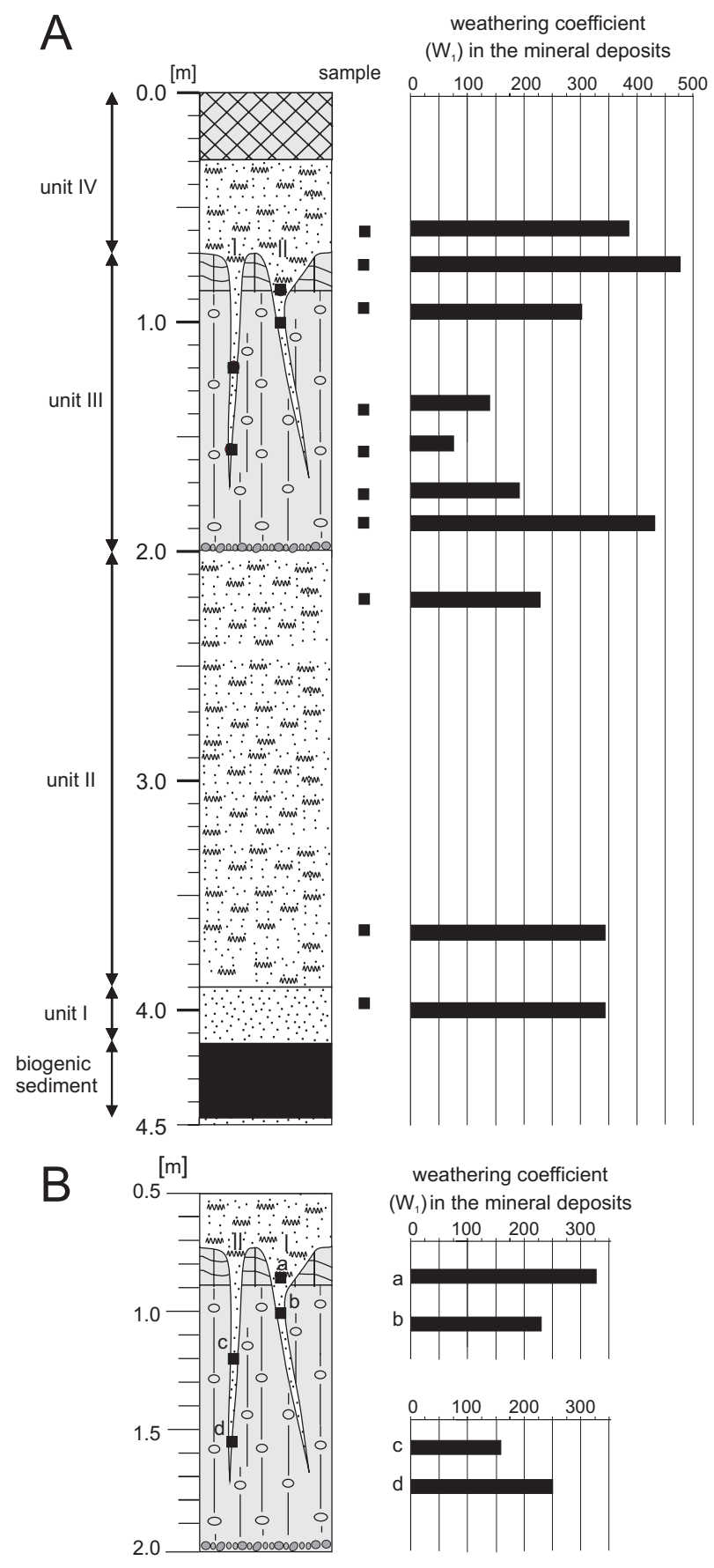

Fig. 6. Weathering coefficient $W_{1}$ in the mineral deposits A: units I, II and III. B: unit IV (ice wedges filled with aeolian deposits).

higher values, but the samples from depths of 3.9 and $4.1 \mathrm{~m}$ have commonly a low content. On average (and except for $\mathrm{Ca}$, which reaches up to $\left.7.3 \mathrm{mg} \bullet \mathrm{g}^{-1}\right)$, the content of the various elements does not exceed $1 \mathrm{mg} \bullet \mathrm{g}^{-1}(\mathrm{Na}-0.02$ $\mathrm{mg} \bullet \mathrm{g}^{-1}, \mathrm{~K}-0.57 \mathrm{mg} \bullet \mathrm{g}^{-1}, \mathrm{Mg}-0.80 \mathrm{mg} \bullet \mathrm{g}^{-1}, \mathrm{Fe}$ $-0.96 \mathrm{mg} \bullet \mathrm{g}^{-1}$, and $\left.\mathrm{Mn} 0.02 \mathrm{mg} \bullet \mathrm{g}^{-1}\right)$. The val- ues of the $\mathrm{Fe} / \mathrm{Mn}$ ratio, which are relatively high at the base of the unit (80.2) and distinctly lower at its top (45) (Fig. 7), suggest changing redox conditions (Boyle, 2001; Borówka, 2007).

Within the entire unit III, sediments are almost devoid of carbonates, what is also indicated by the trace amounts of $\mathrm{Ca}$, ranging from 0.01 to $0.02 \mathrm{mg} \bullet \mathrm{g}^{-1}$. The sediments show a weak alkaline reaction $(\mathrm{pH} 7.3-7.5$ determined in water, $\mathrm{pH}$ : 5.8-6.0 determined in $\mathrm{KCl})$. Just like in unit $\mathrm{I}$, the sediments have a low sodium content, attaining maximally 0.02 $\mathrm{mg} \bullet \mathrm{g}^{-1}$. The amounts of $\mathrm{Mg}, \mathrm{K}$ and Fe are quite different $\left(0.24-0.36 \mathrm{mg} \bullet \mathrm{g}^{-1}, 0.57-0.72 \mathrm{mg} \bullet \mathrm{g}^{-1}\right.$ and $1.18-1.54 \mathrm{mg}^{\bullet} \mathrm{g}^{-1}$, respectively). The sediments are extremely poor in $\mathrm{Mn}\left(0.02 \mathrm{mg}^{\bullet} \mathrm{g}^{-1}\right)$. The values of the $\mathrm{Fe} / \mathrm{Mn}$ ratio are higher than in unit I and vary between 82 and 138 (Fig. 7). In the surficial layer with intense weathering processes, both $\mathrm{Mn}$ and Fe are reduced and migrate; Mn tends to be removed faster than Fe (Borówka, 1992).

With respect to the infilling of the wedges, it should be noticed that the sediment is enriched in elements such as $\mathrm{Na}\left(0.03 \mathrm{mg} \bullet \mathrm{g}^{-1}\right), \mathrm{Mg}(0.40$ $\mathrm{mg} \bullet \mathrm{g}^{-1}$ ), $\mathrm{K}$ (up to $0.86 \mathrm{mg}^{\bullet} \mathrm{g}^{-1}$ ), and Fe (up to $\left.2.1 \mathrm{mg} \bullet \mathrm{g}^{-1}\right)$. Other elements (Ca and $\mathrm{Mn}$ ) are present in much lower amounts. The amount of ferric oxides, $\mathrm{F}_{2} \mathrm{O}_{3}$, is the highest in this material and amounts to $3.1 \%$. The values of the $\mathrm{pH}$ range from 5.6 to 6.1 (determined in $\mathrm{H}_{2} \mathrm{O}$ ) and from 4.1 to 4.8 (determined in KCL) (Fig. 7).

The sediments of unit IV are also decalcified $\left(\mathrm{CaCO}_{3}\right.$ reaches up to $0.2 \%$; $\mathrm{Ca}$ is below the detection limit). The content of the various elements and ferric oxides is lower than in the sediments of unit III: $\mathrm{Na}$ amounts to 0.02 $\mathrm{mg} \bullet \mathrm{g}^{-1}, \mathrm{Mg}$ to $0.20 \mathrm{mg} \bullet \mathrm{g}^{-1}, \mathrm{Mn}$ to $0.1 \mathrm{mg} \bullet \mathrm{g}^{-1}$, and Fe to $1.06 \mathrm{mg}^{\bullet} \mathrm{g}^{-1}$, whereas $\mathrm{Ca}$ is below the limit of determination. The value of $\mathrm{pH}$ (in $\mathrm{H}_{2} \mathrm{O}$ ) is 6.6 and (in $\mathrm{KCl}$ ) 5.9 .

\section{Discussion}

The analyses of the quartz grains' surfaces, of the heavy minerals and of the geochemistry provide a basis for deepening the insight into the palaeogeography of northern Pod- 

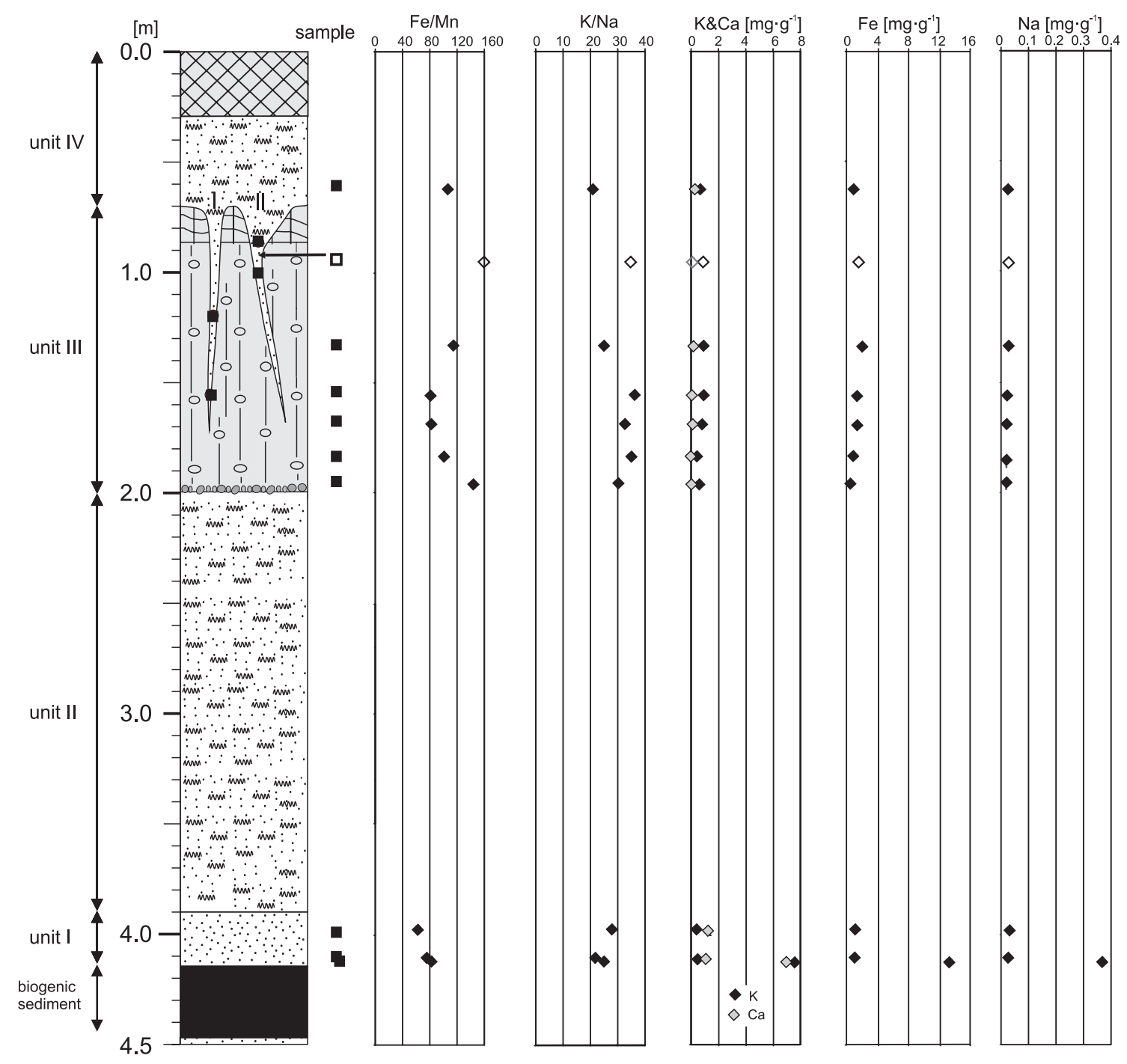

Fig. 7. Geochemical composition of the mineral deposits of units I-IV.

lasie. This concerns (1) the parent material of the mineral sediments, (2) the depositional environment of the mineral sediments overlying the Eemian deposits, and (3) the effect of the periglacial conditions on the characteristics of the sediments.

\subsection{Parent material}

The parent material of the deposits at the Jałówka site consists of glacial sediments of the Wartanian stadial of the Odranian glaciation (late Saalian) (Marks \& Karabanov, 2011). Such sediments form the slope at the foot of which the study site is located. In glacial environments, the heavy-mineral composition is controlled by three main factors: (1) the composition of the source rocks, (2) the resistance of the minerals to mechanical damage (i.e. crushing and abrasion during glacial transport) and (3) chemical weathering at different stages of the glacial/interglacial alternations (Passchier, 2007).

Continental ice sheets erode numerous types of source rocks along their pathway, and the composition of tills in the ice-marginal area reflects the combination of dispersal trains (Passchier, 2007). Most information on sediments exarated by the Wartanian ice sheet 
comes from the analysis of the grains' surfaces, in combination with heavy-mineral analysis.

The presence of quartz grains of the EL, EM/EL and 'other' types (Fig. 4A, B) and the absence of grains representing an aeolian environment (the RM and EM/RM types) prove that the Wartanian ice sheet exarated mainly sediments representing aquatic environments. The high level of rounding of the quartz grains indicates their long-lived presence in an aquatic environment with numerous phases of grain reworking. This may have taken place in a beach environment, within the foreshore or swash-and-backwash zone, or in a fluvial environment. This is supported by the microrelief (dulled surface, solution pits and solution crevasses) on the quartz grains as a result of intensive and most likely long-lived etching. Moreover, the low frequency of V-shaped percussion cracks suggests a low-energy environment (Krinsley et al., 1964). Margolis \& Kennett (1971) and Woronko \& Ostrowska (2009) have suggested that single cracks are characteristic of fluvial environments.

The environmental conditions deduced from the quartz grains are supported by the heavy-mineral analysis. Angular grains of heavy minerals, with ragged edges, indicate strong chemical weathering (Van Loon \& Mange, 2007; Turner \& Morton, 2007). Strongly etched heavy minerals been commonly reported from the sea floor (e.g. Turner \& Morton, 2007), which environment seems a likely source for the sediments at the Jałówka site. It cannot be excluded, however, that the lack of particular minerals is due to their removal from the source sediments by chemical weathering.

The heavy-mineral analysis also indicates that the original environment was subjected to physical mineral sorting on the basis of density and grain size. Amphibole and garnet grains, dominant in the sediments, differ in their density $\left(3.2 \mathrm{~g} / \mathrm{cm}^{3}\right.$ and $4.1 \mathrm{~g} / \mathrm{cm}^{3}$, respectively) (Fig. 3A, B), grain diameter and resistance to crushing in the glacial environment. Garnet grains, for instance, are reduced to their terminal grades after glacial transport over a distance of 80-180 km (Passchier, 2007). According to Passchier (2007) "the terminal grade represents a specific particle size range for each mineral in a till matrix, which depends on the original mineral size in the source rock, and the mechanical stability of each mineral". Amphiboles are larger than garnet, which is compensated for by a higher density.

Within the group with the finest grain size, the mineral species have the largest density, e.g. zircon $\left(4.7 \mathrm{~g} / \mathrm{cm}^{3}\right)$, ilmenite $\left(4.68 \mathrm{~g} / \mathrm{cm}^{3}\right)$ and magnetite $\left(5.1 \mathrm{~g} / \mathrm{cm}^{3}\right)$ (Fig. 3A), all present low percentages. Komar (2007) emphasises that ilmenite and zircon display low-concentration factors, evidencing that both minerals are trapped in concentrated deposits which may occur at the top of a beach, and that they are not carried offshore. Ilmenite and magnetite are also, due to the small sizes of their grains, most difficultly entrained, what intensifies the concentration process. On the other hand, amphibole, with the lowest concentration factor, is one of the most easily entrained heavy minerals (comparably with quartz: Komar, 2007), however, due to its distinctly larger diameter, this mineral remains in the sediment and is concentrated with minerals of the highest density. Following Komar (2007), the higher the density of a mineral, the lower its median grain size at places where concentration takes place, as well as in offshore deposits. This inverse relationship between grain diameter and density also suggests a setting equivalence between several minerals.

Wajda (1970), in studies on the present-day bottom sands of the Polish Baltic Sea coast, states that transparent heavy minerals, such as garnet and zircon, are difficult to dislocate in an aquatic environment due to their fabric. They are concentrated as a result of removal of minerals of lower weight and typify bottom areas affected by hydrodynamic factors, abrasion and bottom erosion of a higher intensity. In bottom sands of the Baltic coast, the highest concentrations of garnet and opaque heavy minerals are recorded in the coastal zone, up to about $10 \mathrm{~km}$ into the sea. Deeper areas are dominated by minerals such as biotite, characteristic of the zone of calm deposition and indicating exaration of marine sediments of shallow-water facies by the ice-sheet. A predominance of amphi- 
bole and garnet among the heavy minerals of a Saalian till was found in The Netherlands by Rappol \& Stoltenberg (1985) and in soils that developed on a basal till of the Weichselian glaciation and on a marginal formation of glacial sediments from the Saalian glaciation in Lithuania (Vareikienè et al., 2007). Similar assemblages of heavy minerals are known from northern Germany (Rappol \& Stoltenberg, 1985). According to these authors, the east-central Baltic sedimentary rocks served as the initial source of heavy minerals for the Saalian till in The Netherlands. Vareikienè et al. (2007) assume that soil-forming sediments representing the Saalian and the Weichselian glaciations originate from the Fennoscandian Shield, which includes Archaean-Proterozoic crystalline rocks and younger recycled sedimentary rocks ranging in age from Cambrian to Palaeogene. At the Jałówka site, the direction of the palaeo-ice flow and the source of the sediments were most likely the same as in Lithuania. Additionally, an identical record of assemblages of heavy minerals as at the Jałówka site was identified in fluvioglacial sediments located north of the study site, near the Polish/Belorussian border (Pochocka-Szwarc et al., 2011).

\subsection{Heavy and light minerals in the four units and their depositional environments}

As mentioned above, the composition of the assemblages of heavy and light minerals can provide valuable information on the depositional environments. This turns out to hold also for units I-IV of the study site.

\subsubsection{Unit I}

The origin of the sediments that build unit I is related to a current at the bottom of a commonly dry valley. The material carried along by the stream undoubtedly included material from the slopes and bottom of this valley, among other material organic deposits of the Eemian interglacial and washed down material that formed part of soils developing on the slopes. This soil material is reflected in the high proportion (over 70\%) of grains representing the 'other' type, the surface of which was shaped mainly by intensive chemical weathering (particularly by precipitation of amorphous silica and clay minerals), and is also supported by the high content of secondary ferric oxides, originating most likely from oxidation processes (Fig. 4A, B). This is further confirmed by the low value of the $\mathrm{Fe} / \mathrm{Mn}$ ratio, in this unit varying between 45 and 80 , which suggests a low energy of the fluvial environment (Fig. 7), as well as by, among the heavy minerals, the large amounts of amphibole, the decreasing amounts of garnet and the very low contributions by magnetite, ilmenite and zircon. Amphibole grains, having a relatively low density and a relatively large size, are moved more easily than denser minerals with a smaller size (Komar, 2007).

Unit I was subjected to selective grain entrainment. Erosion of Eemian sediments is suggested by the geochemical analysis (Fig. 7). The weathering index, $W_{1}$, attains nearly 300 (Fig. 6). Such a high value results from the removal of heavy minerals with a lower resistance to chemical weathering.

\subsubsection{Unit II}

The very high proportions of grains of the $0.1-0.05 \mathrm{~mm}(53.12 \%)$ and $0.05-0.01 \mathrm{~mm}(10 \%)$ fractions in unit II indicate loess-like aeolian sediments. Sediments of a similar origin and grain-size distribution are known from the periglacial zone of the Vistulian in southern Lithuania (Baltrūnas et al., 2007). Their accumulation most likely occurred during MIS 4, when the deterioration of the environment was sufficient to activate aeolian processes at a large scale (Jary, 1996, 2007; Frechen et al., 2003; Balurūnas et al., 2007). Maruszczak (1986) dates the first post-Eemian loess covers (LMn) in southern Poland to Vistulian 2 (MIS $5 b)$, however. The sedimentary particles were transported by low-energy winds over very short distances, what is confirmed by the lack of quartz grains with typical aeolian characteristics (both RM-type grains and EM/RM-type grains) (Fig. 4A). Moreover, the heavy-mineral assemblage shows an increase in amphibole (being a mineral of low specific weight), and 
diminishing amounts of the heaviest minerals (magnetite and ilmenite) (Fig. 3A).

Loesses tend to show a progressive increase in the amounts of platy minerals, such as muscovite in the light fraction and biotite in the heavy fraction (Bateman \& Catt, 2007). It should be mentioned that this trend can be observed for the 0.1-0.05 mm fraction (Chlebowski \& Lindner, 2004). The sediments of unit II contain trace amounts of biotite $(<2 \%)$, but the presence or absence of this mineral, as well as that of other platy minerals, in loess sediments depends on the type of source sediments, not on the processes responsible for the development of such deposits (Chlebowski \& Lindner, 2004) (Fig. 3A).

The sediments originate from deposits that constitute the surrounding slopes, e.g. from windblown soil horizons, as suggested by the occurrence of secondary ferric oxides including brown 'limonitic' aggregates (Fig. 3A), which point at oxidation processes. The weathering index, $W_{1}$, remains at the same level as in unit I, indicating that both units had the same type of source sediments, i.e. local ones, without admixtures of material supplied through long-distance transport.

\subsubsection{Unit III}

The sediments of unit III are characterised by a high content of high-density minerals, such as magnetite, ilmenite and zircon (Fig. 3A). The unit shows a distinct increase, up to $11.4 \%$, in the proportion of minerals that are most resistant to chemical weathering (e.g. zircon and staurolite), accompanied by a decrease in the amounts of garnet and amphibole. Due to the type of transport (solifluction) and the high density of the medium, the heavy minerals were not sorted by density, grain size and shape. Most likely the minerals are derived from assemblages in the glacial sediments building the slope where the solifluction took place.

The weathering index, $\mathrm{W}_{1}$, varies strongly, from over 400 at the basal and top parts to 80 at a depth of $1.55-1.60 \mathrm{~m}$ (Fig. 6A). Such a variability of the weathering index might point at a stack of successive turf-banked solifluction lobes, including horizons affected by intensive chemical weathering. The heavy-mineral com- position is also likely to be associated with sediments exarated by the Saalian ice sheet.

\subsubsection{Unit IV}

The aeolian, sandy sediments filling the icewedge casts and the very poorly sorted sandy/ silty sediments of unit IV contain grains with surfaces that were shaped in aeolian processes. The low proportion of such grains, not exceeding $30 \%$, and including only grains of the EM/ RM type (Fig. 4B), definitely proves, however, that the aeolian processes in northern Podlasie region at the end of the Vistulian glaciation were only short-lived. Similar conclusions have been drawn by Korotaj \& Mycielska-Dowgiałło (1982) from their investigations of the infilling of comparable wedges in the central part of the Kolno Plateau. Mycielska-Dowgiałło (1996) reports, however, that sediments are dominated by grains of the EM/RM type only if the period with much wind activity in a particular area is relatively short (some hundreds of years). If the duration of the aeolian activity increases, the amount of EM/RM grains decreases because they are transformed to RM-type grains.

The only short duration of the aeolian processes in this area most likely resulted from the excessive humidity of the sedimentary particles, which may have been lifted into the air during periods of increased aridity of the sedimentary surface, e.g. during winter.

The infilling of the wedges on the central part of the Kolno Plateau, studied by Korotaj \& Mycielska-Dowgiałło (1982), bears more garnet and less amphiboles in its bottom part, but at the top the proportions are reversed, what can be explained by different specific weights of the minerals. Garnet, with its larger specific weight, accumulates in deeper parts of such wedges, whereas the lighter minerals stay in the top parts. Korotaj \& Mycielska-Dowgiałło (1982) claim that the above mineral distribution indicates degradation of the permafrost and a distinct increase in humidity of the sediments in the wedges. Indirectly, such a distribution of the minerals suggests a significant duration of the permafrost degradation. The tendency of heavier minerals to concentrate at the bottom of the sand wedges was also noticed at Jałówka (wedge I), where the sorting by den- 
sity affected not only garnet, but also magnetite and ilmenite (Fig. 3B). It seems, however, that other possible interpretations, including different sizes of the heavy mineral grains may also have played a role. Middleton (1970) and Komar (2007) suggest that sorting of heavy minerals is produced by the smaller particles (garnet) tending to fall into spaces between the larger grains. Simultaneously, larger ones (amphibole) are pushed upwards. In narrow and straight wedges (wedge II) an opposite distribution of the heavy minerals grains was found. This suggests that permafrost degradation was quicker, too short-lived to allow for sorting of heavy minerals by density.

The sediments of unit IV show, compared with those filling the wedges, an increase in the weathering index (from 150-250 to over $350)$, resulting from the relative enrichment in garnet (Fig. 6B), which is strongly resistant to abrasion, in the aeolian environment (Kamińska et al., 1986), and from the impoverishment of platy minerals (Mycielska-Dowgiałło, 1993; Barczuk \& Mycielska-Dowgiałło, 2001).

\subsection{Periglacial transformations of the sediments}

Under periglacial conditions, the sediments of the Jałówka site were probably subjected to strong weathering, most intensively in the active layer that was about $60-70 \mathrm{~cm}$ thick during the LGM. The strong weathering processes become clear from the geochemical analyses, which show minor amounts of some chemical elements $(\mathrm{Na}, \mathrm{K}, \mathrm{Mg})$ and complete decalcification of the deposits. Ferric oxides are present in small amounts, ranging from 1.3 to $3.0 \mathrm{mg} \bullet \mathrm{g}^{-1}$, having the highest values in unit III at a depth of 1.2-1.7 m (Fig. 7).

Ostroumov et al. (1998) state that "The concentration and dispersion of chemical elements under the influence of permafrost is poorly understood." Nevertheless, according to fieldwork carried out in the Kolyma Lowland (NW Siberia) and elsewhere, the maximum concentrations of mobile forms of elements occur at the bottom of the active layer or in the upper part of the transition layer. This is because per- mafrost blocks infiltration of surface water, causing its concentration in the active layer (Woo \& Xia, 1995). Part of the pore water migrates into the upper layer of the permafrost and results in an ice-rich transition layer (Ostroumov et al., 1998).

Geochemical sedimentation at the bottom of the permafrost results from migration of ions into the frozen soil during freezing (Ostroumov et al., 1998). The low content of several chemical elements, among which $\mathrm{Na}, \mathrm{Mg}$, $\mathrm{K}$ and $\mathrm{Fe}$, in the deposits at the Jałówka site results from erosion (by streams or by mass movement), affecting the sediments of the active layer. The different resistance to weathering of the various chemical compounds allows for an estimation of the type of the processes that prevail in the catchment area (Franz et al., 2006). Minimum values of $\mathrm{Na}$ in a sediment indicate its development under conditions of intensive weathering. Na passes into solution more quickly than $\mathrm{K}$, which is additionally captured by secondary clayey minerals (Migaszewski \& Gałuszka, 2007), thus becoming relatively abundant in the area of weathering. Following Borówka (1992), potassium is fixed by colloids about 25 times stronger than sodium. Analysis of the ratio between the total $\mathrm{Na}$ and the total $\mathrm{K}$ amounts thus provides a proxy for the identification of the type of denudation processes that dominated in the catchment area. Similar relationships of the $\mathrm{K} / \mathrm{Na}$ ratio can, according to Franz et al. (2006), be used as an indicator of weathering intensity (Fig. 7).

Analysis of the K/Na ratio within the section under study indicates that the mineral sediments were dominated by strong weathering, the maximum effects of which may be assigned to the period when the basal part of unit III formed at a depth of approx. $1 \mathrm{~m}$ below the sedimentary surface (Fig. 7). A similar pattern is suggested by the $\mathrm{Na} / \mathrm{K}$ ratio, lower values of which are recognised as an effect of mechanical denudation. At the study site, the ratio shows extremely low values, not exceeding 0.1

The grain-surface analysis of the sediments shows a high or even very high proportion of broken grains (C) (Fig. 4A, B). As some of the fractures are completely fresh and some show precipitation, the damage of the quartz grains 
probably occurred in two phases, separated by a period dominated by chemical weathering. It appears that breakage of grains sometimes was followed by precipitation, but that other grains were broken during this latter stage. Both types of weathering may have resulted from freeze/ thaw alternations, for instance in the active layer (e.g. Kowalkowski \& Mycielska-Dowgiałło, 1985; Wright, 2000; Dietzel, 2005; Woronko, 2007, 2012b; Woronko \& Hoch, 2011).

Dietzel (2005) performed a series of experiments simulating repeated freeze/thaw alternations; these confirmed that silica precipitates on the surface of grains. However, it should be noted that this precipitation is very complex and not yet fully understood. Similar conclusions have been drawn by Woronko (2007) and Woronko \& Hoch (2011). Breakage of quartz grains may result from the presence of gas/liquid inclusions (Rogov, 1982; Konishchev \& Rogov, 1993; French \& Guglielmin, 2000; French, 2007; Woronko, 2012b). The content of quartz grains that are broken due to an increase in volume of freezing water, easily increases in the active layer (Woronko, 2012b).

\section{Conclusions}

A combination of heavy- and light-mineral analyses and geochemical analyses of sediments from the Jałówka site made it possible to determine the source material of the glacial sediments of the Wartanian stadial of the Odranian glaciation. During the Vistulian glaciation, when the land-ice cover did not reach the study area, the deposits were subjected to erosion by streams, wind and slope processes, partly under periglacial conditions.

The post-sedimentary (diagenetic) changes were also determined. It is concluded that the material of the Saalian till originated ultimately from shallow-marine sediments that were eroded in such a way that the heavy-mineral grains became sorted by density and size; the most likely source material are east-central Baltic sedimentary rocks.

Under periglacial conditions, the sediments were affected by strong weathering and by mechanical crushing and abrasion. This result- ed in precipitation of silica on the surfaces of quarts grains, but these surfaces became also damaged; in addition, leaching of chemical elements took place. These processes resulted in complete decalcification of the sediments and in diminishing concentrations of $\mathrm{Na}, \mathrm{K}, \mathrm{Mg}$ and $\mathrm{Ca}$. Simultaneously, aeolian activity affected the area, but the intensity was low and the duration very short; as a consequence, the structural features of the sediments show only minimum aeolian abrasion. The processes had also insufficient influence to change the landform distinctly.

Taken all this together, the Jałówka site provides a valuable record of environmental changes in northern Podlasie during the of Late Pleistocene.

\section{References}

Baltrūnas, V., Švedas, K. \& Pukelytè, V., 2007. Palaeogeography of South Lithuania during the last ice age. Sedimentary Geology 193, 221-231.

Banaszuk, H., 1998. Ranges and course of the Wisła and Warta glaciations in north-eastern Poland in the latest studies. [In:] K. Pękala (Ed.): Materiaty IV Zjazdu Geomorfologów Polskich. Wydawnictwo UMCS, Lublin, 233-240.

Banaszuk, H., 2001. O zasięgu zlodowacenia wisły w Polsce północno-wschodniej na podstawie badań geomorfologicznych i termoluminescencyjnych [Defining the range of the Vistulian glaciation in north-eastern Poland on the basis of geomorphological and thermoluminestence investigations]. Przegląd Geograficzny 73, 281-305.

Banaszuk, H. \& Banaszuk, P., 2010. Zagadnienia morfogenezy Niziny Północnopodlaskiej [On the morphogenesis of the Północnopodlaska Lowland]. Politechnika Białostocka, 170 pp.

Barczuk, A. \& Nejbert, K., 2007. Analiza minerałów nieprzeźroczystych $\mathrm{w}$ badaniach skał okruchowych [Opaque-mineral analysis for investigation of clastic rocks]. [In:] E. Mycielska-Dowgiałło \& J. Rutkowski (Eds): Badania cech teksturalnych osadów czwartorzędowych $i$ wybrane metody oznaczania ich wieku [Investigation of the textural features of Quaternary sediments and some dating methods]. WSWPR, Warszawa, 205-228.

Barczuk, A. \& Mycielska-Dowgiałło, E., 2001. Znaczenie składu mineralnego dla rozpoznania obecności procesów eolicznych [Interpretation of aeolian processes on the basis of the composition of mineral sediments]. [In:] E. Mycielska-Dowgiałło \& J. Rutkowski (Eds): Eolizacja osadów jako wskaźnik stratygraficzny czwar- 
torzędu [Aeolisation of sediments as an indicator of Quaternary stratigraphy]. WGSR, Warszawa, 39-42.

Bateman, R.M., 1989. Interpretation of heavy mineral assemblages: outmoded art or undervalued science? 28th International Geological Congress (Washington, DC) Abstracts 1, 97-98.

Bateman, R.M. \& Catt, J.A., 2007. Provenance and paleoenvironmental interpretation of superficial deposits, with particular references to post-depositional modification of heavy mineral assemblages. [In:] M.A. Mange \& D.T. Wright (Eds): Heavy minerals in use. Developments in Sedimentology (Elsevier, Amsterdam) 58, 151-188.

Borówka, R.K., 1992. Przebieg i rozmiary denudacji w obrębie śródwysoczyznowych basenów sedymentacyjnych podczas późnego vistulianu i holocenu [The pattern and magnitude of denudation in intraplateau sedimentary basins during the late Vistulian and Holocene]. Wydawnictwo UAM, Seria Geografia 54, 177 pp.

Borówka, R.K., 2007. Geochemiczne badania osadów jeziornych strefy umiarkowanej [Geochemical research on lacustrine deposits in moderate zone]. Studia Limnologica et Telmatologica 1, 33-42.

Boyle, J.F., 2001. Inorganic geochemical methods in palaeolimnology. [In:] W.M. Last \& J.P. Smol (Eds): Tracking environmental change using lake sediments. Physical and Geochemical Methods (Kluwer Academic Publishers, Dordrecht) 2, 83-141.

Briant, R.M., Coope, G.R., Preece, R.C., Keen, D.H., Boreham, S., Griffith, H.I., Seddon, M.B. \& Gibbard, P.L., 2004. Fluvial system response to Late Devensian (Weichselian) aridity, Baston, Lincolnshire, England. Journal of Quaternary Science 19, 479-495.

Brud, S. \& Kupryjanowicz, M., 2002. Eemian Interglacial deposits at Haćki near Bielsk Podlaski: implications for the limit of the last glaciation in northeastern Poland Geological Quarterly 46, 75-80.

Cailleux, A., 1942. Les actionnes éoliennes périglaciaires en Europe. Mémoires de la Société Géologique de France $41,1-176$.

Chlebowski, R. \& Lindner, L., 2004. Aspekty mineralogiczne w metodyce badań lessów na przykładzie lessów polskich i ukraińskich [Mineralogical issues in the methodology of loess analysis with examples from the loesses of Poland and Ukraine]. [In:] A. Kostrzewski (Ed.): Geneza, litologia, i stratygrafia utworów czwartorzędowych [Genesis, lithology and stratigraphy of Quaternary deposits.] 4. Wydawnictwa Naukowe UAM Poznań, 17-36.

Derkachev, A.N. \& Nikolaeva, N.A., 2013. Possibilities and restrictions of heavy-mineral analyses for the reconstruction of sedimentary environments and source areas. Geologos 19 (this issue), 147-158.

Dietzel, M., 2005. Impact of cyclic freezing on precipitation of silica in $\mathrm{Me}-\mathrm{SiO}_{2}-\mathrm{H}_{2} \mathrm{O}$ systems and geochemical implications for cryosoils and -sediments. Chemical Geology 216, 79-88.

Durn, G., Aljinovic D., Crnjakovic, M. \& Lugovic, B., 2007. Heavy and light mineral fractions indicate polygenesis of extensive terra rossa soils in Istria, Croatia. [In:] M.A. Mange \& D.T. Wright (Eds): Heavy miner- als in use. Developments in Sedimentology (Elsevier, Amsterdam) 58, 701-737.

Dzierżek, J. \& Stańczuk, D., 2006. Record and palaeogeographical implications of Pleistocene periglacial processes in the Drohiczyn Plateau, Podlasie Lowland (Eastern Poland). Geological Quarterly 50, 219-228.

Dylik, J., 1953. O peryglacjalnym charakterze rzeźby środkowei Polski [The periglacial character of the relief of central Poland]. Łódzkie Towarzystwo Naukowe 24, 109 pp.

Ehlers, J. \& Gibbard, P., 2008. Extent and chronology of Quaternary glaciations. Episodes 31, 211-218.

Florek, W. \& Mycielska-Dowgiałło, E., 1991. Structural and textural character of alluvial deposits as an indicator of environmental conditions. [In:] F. Gullentops (Ed.): Wetlands in Flanders. Aardkundige Mededelingen 6, 173-179.

Florek, W., Florek, E. \& Mycielska-Dowgiałło, E., 1987. Morphogenesis of the Vistula valley between Kępa Polska and Płock in the Late Glacial and Holocene. [In:] L. Starkel (Ed.): Evolution of the Vistula river valley during the last 15000 years. Part II. Geographical Studies, Special Issue 4, 189-205.

Franz, S.O., Schwark, L., Brüchmann, C., Scharf, B., Klingel, R., Van Alstine, J.D., Cagatay, N. \& Ülgen, U.B., 2006. Results from a multi-disciplinary sedimentary pilot study of tectonic Lake Iznik (NW Turkey) - geochemistry and paleolimnology of the recent past. Journal of Paleolimnology 35, 715-736.

French, H.M., 2007. The periglacial environment ( $3^{\text {rd }}$ ed.). J. Wiley and Sons, Chichester, $458 \mathrm{pp}$.

French, H.M. \& Guglielmin, M., 2000. Cryogenic weathering of granite, Northern Victoria Land, Antarctica. Permafrost and Periglacial Processes 11, 305-314.

French, H.M. \& Shur, Y, 2010. The principles of cryostratigraphy. Earth-Science Reviews 101, 190-206.

Goździk, J., 1980. Zastosowanie morfoskopii i graniformametrii do badań osadów w kopalni węgla brunatnego "Bełchatów" [Application of morphoscopy and granimormometry for investigations of deposits in the "Bełchatów" brown coal mine]. Studia Regionalne 4, 101-114.

Haldorsen, S., Jørgensen, P., Rappol, M. \& Riezebos, P.A., 1989. Composition and source of the clay-sized fraction of Saalian till in The Netherlands. Boreas 18, 89-97.

Jary, Z., 1996. Chronostratygrafia oraz warunki sedymentacji lessów południowo-zachodniej Polski na przykładzie Płaskowyżu Głubczyckiego i Wzgórz Trzebnickich [Chronostratigraphy and conditions of loess sedimentation in north-western Poland, with the Głubczyce Plateau and the Trzebnica Hills as examples]. Acta Universitatis Wratislaviensis, Studia Geographica 1766, 99 pp.

Jary, Z., 2007. Zapis zmian klimatu w górno plejstoceńskich sekwencjach lessowo-glebowych w Polsce $i$ w zachodniej Ukrainie [The record of the climate change in upper Pleistocene loess-soil successions in Poland and West Ukraine]. Promotor Media Wydawnictwo, Wrocław, $136 \mathrm{pp}$. 
Kamińska, R., Konecka-Betley, K. \& Mycielska-Dowgiałło, E., 1986. The Liszyno dune in the Vistula Valley (east of Płock). Biuletyn Peryglacjalny 31, 141-162.

Kasse, C., Vandenberghe, J., Van Huissteden, J., Bohncke, S.J.P. \& Bos, J.A.A., 2003. Sensitivity of Weichselian fluvial systems to climate change (Nochten mine, eastern Germany). Quaternary Science Reviews 22, 2141-2156.

Komar, P.D., 2007. The entrainment, transport and sorting of heavy minerals by waves and currents. [In:] M.A. Mange \& D.T. Wright (Eds): Heavy minerals in use. Developments in Sedimentology (Elsevier, Amsterdam) 58, 3-48.

Konishchev, N.V. \& Rogov, V.V., 1993. Investigations of cryogenic weathering in Europe and Northern Asia. Permafrost and Periglacial Processes 4, 49-64.

Korotaj, M. \& Mycielska-Dowgiałło, E., 1982. Würmian periglacial processes in the Kolno Plateau on the basis of sedimentological investigations with the use of a scanning electron microscope. Biuletyn Peryglacjalny 29, 53-76.

Kowalkowski, A., Mycielska-Dowgiałło, E. 1985. Weathering of quartz grain in the liquefied horizon of permafrost solonchaks in the arid steppe zone, Central Mongolia. Catena 12, 179-190.

Krinsley, D.H., Takahashi, T., Silberman, M.L. \& Newman, W.S., 1964. Transportation of sand grains along the Atlantic shore, Long Island, New York: an application of electron microscopy. Marine Geology 2, 100-120.

Krumbein, W.C., 1941. Measurement and geological significance of shape and roundness of sedimentary particles. Journal of Sedimentary Petrology 11, 64-72.

Krzywicki, T., 2002. The maximum ice sheet limit of the Vistulian glaciation in north eastern Poland and neighbouring areas. Geological Quarterly 46, 165-188.

Krzywicki, T., 2012. Jaki zasięg zlodowacenia wisły w rejonie górnej Biebrzy? [What with the Vistulian ice sheet limit for the Upper Biebrza river Valley]. [In:] M. Błaszkiewicz \& F. Brose (Eds): XIX Konferencja Stratygrafia Plejstocenu Polski, pt. Korelacja osadów plejstocenu na pograniczu polsko-niemieckim w Dolinie Dolnej Odry (2012). PIG-BIP, 69-73.

Kupryjanowicz, M., 1991. Eemian, early and late Vistulian, and Holocene vegetation in the region of Machnacz peat-bog near Bialystok (NE Poland). Acta Palaeobotanica 31, 215-225.

Kupryjanowicz, M., 2007. Water level changes in the Eemian lakes and peat-bogs in the north Podlasie. Przegląd Geologiczny 55, 336-342.

Kupryjanowicz, M., 2008. Vegetation and climate of the Eemian and early Vistulian lakeland in Northern Podlasie. Acta Paleobotanica 48 (1), 130 pp.

Ludwikowska-Kędzia, M., 2013. The composition of transparent heavy minerals in Quaternary sediments of the Kielce-Łagów valley (Holy Cross Mountains, Poland). Geologos 19 (this issue), 95-129.

Łydka, K. \& Turnau-Morawska, M., 1967. Minerały ciężkie $\mathrm{w}$ osadach trzeciorzędowych i plejstoceńskich w Marantowie k. Konina [Heavy minerals in Tertiary and Pleistocene deposits, Marantów site near Konin]. Prace Instytutu Geologicznego Warszawa 48, 137-144.

Marcinkowski, B. \& Mycielska-Dowgiałło, E., 2013. Heavy-mineral analysis in Polish investigations of Quaternary deposits: a review. Geologos 19 (this issue), 5-23.

Marks, L., 2012. Timing of the Late Vistulian (Weichselian) glacial phases in Poland. Quaternary Science Reviews 44, 81-88.

Marks, L. \& Karabanov, A. (Eds), 2011. Mapa geologiczna pótnocnej części obszaru przygranicznego Polski i Białorusi, 1:250 000, z tekstem objaśniającym [Geological map of the northern part of the Polish/Belarus frontier at a scale of 1: 250 000, with explanatory text]. Państwowy Instytut Geologiczny/Państwowy Instytut Badawczy, Warszawa.

Margolis, S. \& Kennett, J.P., 1971. Cenozoic, paleoglacial history of Antarctica, recorded in subarctic deep-sea cores. American Journal of Science 271, 36 pp.

Maruszczak, H., 1986. Lessy w Polsce. Ich stratygrafia oraz interpretacja paleogeograficzna [Loesses in Poland, their stratigraphy and paleogeographical interpretation]. [In:] H. Maruszczak (Ed.): Problems of the stratigraphy and palaeogeography of loesses. UMCS, Lublin, 1-200.

Micun, K., 2004. Geneza i rozwój rzeźby Kotliny Biebrzy Górnej [Genesis and development of the upper Biebrza valley relief]. Ph.D. thesis, WGiSR University of Warsaw, Warszawa.

Micun, K., 2006. Development of the peatlands in the Czapielówka stream spring zone against the background of the Knyszyńska Forest relief. Polish Journal of Environmental Science 15 (5D), 21-25.

Micun, K., 2008. Zróżnicowanie litologiczne osadów w różnych częściach doliny Kamiennej na Wzgórzach Sokólskich na tle jej genezy [Lithological differentiation of sediments in different parts of the Kamienna valley in the Sokółka Hills against the background of its origin]. Landform Analysis 9, 160-163.

Micun, K., 2009. Lacustrine deposits in northern part of the Knyszyńska Forest - the remains of water bodies. Journal of Water Land Development 13b, 137-147.

Middleton, G.V., 1970. Experimental studies related to problems of flysch sedimentation. [In:] J. Lajoie (Ed.): Flysch sedimentology in North America. Geologic Association of Canada, Special Paper 7, 253-272.

Migaszewski, Z. \& Gałuszka, A., 2005. Podstawy geochemii środowiska [Basics of environmental geochemistry]. Wydawnictwa Naukowo-Techniczne, Warszawa, 574 pp.

Mojski, J.E., 2005. Ziemie Polskie w czwartorzędzie. Zarys morfogenezy [Polish lands in the Quaternary. Morphogenetic outline]. Państwowy Instytut Geologczny, Warszawa. 404 pp.

Morton, A., Hounslow, M.W. \& Frei, D., 2013. Heavy-mineral, mineral-chemical and zircon-age constraints on the provenance of Triassic sandstones from the Devon coast, southern Britain. Geologos 19 (this issue), 67-85.

Mycielska-Dowgiałło, E., 1992. Desertification on the basis of sedimentological features of dune deposits. Geographica Polonica 60, 181-195. 
Mycielska-Dowgiałło, E., 1993. Estimates of Late Glacial and Holocene aeolian activity in Belgium, Poland and Sweden. Boreas 22, 165-170.

Mycielska-Dowgiałło, E. \& Cichosz-Kostecka, A., 1987. Cechy tekstualne osadów aluwialnych Brenty (północne Włochy) [Textural features of Brenta alluvium (N Italy)]. Sprawozdania z Badań Naukowych 7, 91-93.

Mycielska-Dowgiałło, E. \& Woronko, B., 1998. Analiza obtoczenia i zmatowienia powierzchni ziarn kwarcowych frakcji piaszczystej i jej wartość interpretacyjna [Rounding and frosting analysis of quartz sand-grain surfaces and their interpretative significance]. Przeglad Geologiczny 46, 1275-1281.

Ostroumov, V., Siegert, Ch., Alekseev, A., Demidov, V. \& Alekseeva, T., 1998. Permafrost as a frozen geochemical barrier. Proceedings 'Permafrost' - Seventh International Conference (Yellowknife, Canada). Collection Nordicana 55, 855-859.

Passchier, S., 2007. The use of heavy minerals in the reconstruction of ice-sheet drainage patterns: an example from the edge of the East Antarctic ice sheet. [In:] M.A. Mange \& D.T. Wright (Eds): Heavy minerals in use. Developments in Sedimentology (Elsevier, Amsterdam) 58, 677-699.

Pochocka-Szwarc, K., Woronko, B., Krzywicki, T. \& Rychel, J., 2011. Interpretacja budowy geologicznej $\mathrm{w}$ odsłonięciach reperowych [The interpretation of geological structures in benchmark outcrops]. [In:] L. Marks \& A. Karabanov (Eds): Mapa geologiczna pótnocnej części obszaru przygranicznego Polski i Białorusi 1: 250 000. [Geological map of the northern part of the Polish/Belarus frontier, scale 1: 250,000]. PIG-PIB, Warszawa, 30-44.

Racinowski, R. \& Rzechowski, J., 1969. Minerały ciężkie w glinach zwałowych Polski Środkowej [Heavy minerals in boulder clays of central Poland]. Kwartalnik Geologiczny 13, 479-490.

Rappol, M. \& Stoltenberg, H.M.P., 1985. Compositional variability of Saalian till in The Netherlands and its origin. Boreas 14, 33-50.

Rizzetto, F., Mycielska-Dowgiałło, E. \& Castiglioni, G.B., 1998. Some aeolian features in the Po plain near Este (North Italy). Geografia Fisica e Dinamica Quaternaria 21, 245-253.

Rogov, V.V., 1982. Quartz particle surfaces as evidence of cryogenic weathering. Problems of Cryolithology 10, 68-75. (in Russian)

Rychel, J., Karasiewicz, M.T., Krześlak, I., Krzywicki, T., Marks, L., Noryśkiewicz, B., Pochocka-Szwarc, K. \& Woronko B., 2012. Peryglacjalne przekształcenie rzeźby Wzgórz Sokólskich w ostatnim okresie zimnym [Periglacial transformations of the Sokółka Hills relief during the last cold period]. [In:]: D. Dzieduszyńska \& M. Roman (Eds): Czynniki różnicowania rzeźby Niżu Polskiego (Uniejów, 2012), 71-73.

Rychel, J., Karasiewicz, M.T., Krześlak, I., Marks, L., Noryśkiewicz, B. \& Woronko, B. Paleogeography of the environment in north-eastern Poland recorded in an Eemian sedimentary basin, based on the example of Jałówka site. Quaternary International (in press).
Stephani, E., Fortier, D. \& Shur, Y., 2010. Applications of cryofacies approach to frozen ground engineering - case study of a road test site along the Alaska Highway (Beaver Creek, Yukon, Canada). GEO 2010, 476-483.

Turner, G. \& Morton, A.C., 2007. The effects of burial diagenesis on detrital heavy mineral grain surface. [In:] M.A. Mange \& D.T. Wright (Eds): Heavy minerals in use. Developments in Sedimentology (Elsevier, Amsterdam) 58, 393-412.

Van Loon, A.J., 1972/1973. "Habitus" of some heavy minerals from the Tertiary of Southern Limburg (The Netherlands). Mededelingen van de Rijks Geologische Dienst, Nieuwe Serie 23, 39-67.

Van Loon, A.J., 2009. Unravelling the enigmas of the 'silver sands' in the Dutch/German/Belgian border area. Netherlands Journal of Geosciences 88, 133-145.

Van Loon, A. \& Mange, A.C., 2007. 'In situ' dissolution of heavy minerals through extreme weathering, and the application of survival assemblages their dissolution characteristics to correlation of Dutch and German silver sands. [In:] M.A. Mange \& D.T. Wright (Eds): Heavy minerals in use. Developments in Sedimentology (Elsevier, Amsterdam) 58, 189-213.

Van Vliet-Lanoë, B., 2010. Frost action. [In:] G. Stoops, V. Marcellino \& F. Mees (Eds): Interpretation of micromorphological features of soils and regoliths. Elsevier, London, 81-108.

Vareikienė, O., Marmo, J., Chernet, T. \& Laukkanen, J., 2007. Results of heavy mineral pre-concentration by the Knelson for the geochemical study of soil: a case study in Lithuania. Geologija 60, 1-9.

Vieira, G. T., Mycielska-Dowgiałło, E. \& Woronko, B., 2003. Sedimentological analysis of sandy-gravel accumulations, Serra da Estrela plateau (Portugal). Landform Analysis 4, 99-107.

Wachecka-Kotkowska, L. \& Ludwikowska-Kędzia, M., 2013. Heavy-mineral assemblages from fluvial Pleniglacial deposits of the Piotrków Plateau and the Holy Cross Mountains - a comparative study. Geologos 19 (this issue), 131-146.

Wajda, W., 1970. Heavy minerals of the bottom sand (Polish) Baltic Coast. Annales de la Société Géologique de Pologne 40, 131-149.

Weckwerth, P. \& Chabowski, M., 2013. Heavy minerals as a tool to reconstruct river activity during the Weichselian glaciation (Torun Basin, Poland). Geo$\log o s 19$ (this issue), 25-46.

Weibel, R. \& Friis, H., 2007. Alteration of opaque heavy minerals as a reflection of the geochemical conditions in depositional and diagenetic environments. [In]: M.A. Mange \& D.T. Wright (Eds): Heavy minerals in use. Developments in Sedimentology (Elsevier, Amsterdam) 58, 277-303.

Woo, Ming-ko \& Xia, Z., 1995. Suprapermafrost groundwater seepage in gravelly terrain, Resolute, NWT, Canada. Permafrost and Periglacial Processes 6, 57-72.

Woronko, B., 2012a. Records of aeolian processes in the Pleistocene sandy sediments in selected areas of central and north-eastern Poland. WGiSR UW, Warszawa, 134 pp.

Woronko, B., 2012b. Micromorphology of quartz grains as a tool in the reconstruction of periglacial environ- 
ment. [In:]: P. Churski (Ed.): Contemporary issues in Polish geography, Bogucki Wydawnictwo Naukowe, Poznań, 111-131.

Woronko, B. \& Hoch, M., 2011. The development of frost-weathering microstructures on sand-sized quartz grains: examples from Poland and Mongolia. Permafrost and Periglacial Processes 22, 214-227.

Woronko, B. \& Ostrowska, M, 2009. Wpływ środowiska fluwialnego na charakter powierzchni ziarn kwarcowych - dyskusja [The influence of a fluvial environment on the micromorphology of quartz grain surfaces - discussion]. [In:] A. Kostrzewski \& R. Paluszkiewicz (Eds): Genesis, lithology and stratigraphy of Quaternary deposits 5, 605-622.
Wright, J.S., 2000. The spalling of overgrowths during experimental freeze - thaw of quartz sandstone as mechanism of quartz silt production. Micron 31, 631-638.

Wrotek., K, 2009. Objaśnienia do Szczegótowej mapy geologicznej Polski w skali 1:50,000, arkusz Dąbrowa Białostocka (225) [Explanatory text to the Detailed geological map of Poland, scale 1:25,000, Dąbrowa Białostocka sheet (225)]. CAG PIG-PIB Instytut Geologiczny, 428, 59 pp.

Manuscript received: 17 January 2013 Revision accepted: 8 March 2013 